\title{
Fathers' Perceptions in the Education of Children with Working Mothers
}

\author{
Ajeng Teni Nur Afriliani ${ }^{1, *}$ Hani Yulindrasari ${ }^{1}$
}

\author{
${ }^{1}$ School of Postgraduate Studies, Universitas Pendidikan Indonesia, Bandung, Indonesia \\ *Corresponding author. Email: ajengteninurafriliani@upi.edu
}

\begin{abstract}
Indonesia is one of the largest source countries of migrant workers. In 2018, Indonesia was ranked as the 2nd most migrant workers sender country in ASEAN after the Philippines. Migrant workers have to leave their families and/or their children. BNP2TKI reported that between 2011 and January 2018, 60\% of the total number of Indonesian Migrant Worker (IMW) are women. Many of them left very young children. The absence of parents, especially mothers since the early age hypothetically affects the children's development. Reviewing existing literature about migrant workers' family and children, this paper argues that traditional migration where women leave their families has created a change in family structure and gender division of labor in the family. We recommend further investigation on social perception about the changing roles between father and mother.
\end{abstract}

Keywords: Father involvement, parenting, childcare with migrant worker mothers

\section{BACKGORUND}

Indonesia is the second largest migrant workers supplier in ASEAN after the Philippines (Rania, 2018). Traditional migration in Southeast Asia especially in Indonesia and the Philippines began in the 1970-1980s as a strategy to improve the family's economy (Lam \& Yeoh, 2016). Low rate of employment, lack of local job vacancy, high inflation and low economic growth drive women to migrate to cities or countries with better economic growth to earn a living (Asriani \& Amalia, 2014). Economically, international migrant workers significantly contribute to the improvement of the household's welfare (Purwatiningsih, 2016). One of the consequences of migrating is the separation of families. Migrant worker mothers have to live away from her children and husband. The separation changes the family structure and the division of labour between the husband and the wife. There are many husbands willingly take over the childcare duty, which is traditionally mother's role. Therefore, we argue that the migrant workers family could be the agent of family transformation in term of structure and gender division of labour.

\section{INDONESIAN MIGRANT WORKERS}

As the fourth most populous country in the world, Indonesia always faces challenges in providing sufficient local employment opportunity for the people. Thus, working outside the country becomes an option. High demand for female domestic workers in high income countries becomes opportunity for the lower income countries with workforce surplus to send their workforce abroad (Raharto, 2016).
The need to improve the family economic condition out of poverty have then become the driving force for women to join the workforce working abroad (Sumardiani, 2014). The majority of Informal Women Migrant Workers (IWMW) came from regions and families with low social economic status, low educational background and did not have professional skills (Sukesi, Endang, Agustina, \& Nur, 2017). Indonesian international migrant workers is always dominated by married women. BNP2TKI (National Agency for Placement and Protection of Indonesian Workers) reported that by July 2019 women dominated $71 \%$ of total migrant worker placements. BNP2TKI claims that the percentage of women migrant workers increases every year. The phenomenon of Indonesian migrant workers is like two sides of a coin where there are positive and negative sides in their departure. The positive side is related to economic growth. In the five years period of 2013-2018, Indonesian international migrant workers contributed as much as US \$ 11 billion remittance (Bank Indonesia, 2019). Thus, Indonesian Migrant Workers (BMI) are labeled as the Indonesian remittance heroes who improve family welfare and reduce national poverty rate. On the other side, International migration often leads to the separation of family members, creating greater dependence on nuclear families, weakening wider family relationships, and consequently expanding the role of nuclear family members, especially women (Gonzalez cited in Hugo, 2002). The family should adjust to the inevitable change caused by the migration, such as the gap of maternal childcare. Fathers and the extended families should make adjustment to fill in the gap. 


\section{CHANGES IN STRUCTURE}

Migrating abroad means changing the mode of parental involvement in child-care. As suggested by ECMI / AOS Manila, SMC \& OWWA (Lam \& Yeoh, 2019) claim that the absence of a or both parents is known to cause some displacement, disruption and changes in caregiving arrangements in the family. The dominant paradigm in the community about parenting which prescribe mothers as the main caregivers of children and fathers as the breadwinner has to be shifted (Wulan et al., 2018; Arnold \& Wall, 2007). Conventional gender ideology underlies the division of labour between husband and wife; fathers and mothers have different roles in caregiving (Yulindrasari \& McGregor, 2011). Mothers is gentle and caring while father is wise and disciplined (Chae \& Lee, 2011). Work and the obligations of the main roles of fathers and mothers in the family have been clearly constructed and segregated (Wulan et al., 2018). Mothers' roles are to instill physical and spiritual ties, social skills related to something that is expressive, emotional or a combination of the two. The mother is in charge of entertaining, caring for, reconciling children in distress. Mothers are also responsible for the household, from giving birth to children and raising them in the family, to cooking food and caring for their husbands, to build a peaceful and prosperous household (Mulyana, Kismiyati, \& Meria, 2019). While the father is the leader who organize the family labor for production, generating income for the family and resolve political conflict (Hobson \& Noyes, 2011). However, the families of migrant workers face a different reality. The ideological prescription of family and parenting does not apply in the migrant families (Mulyana, et al., 2019).

The departure of the mother becomes a migrant worker changes the family structure in the surrounding community. A traditional family structure consists of father, mother and child/children. Ideologically, mother is the caregiver and housekeeper, and the father is the main breadwinner. In the women migrant worker families, the arrangement is often the opposite. The mother became the breadwinner and the father is the caregiver.

The changing structure of the women migrant worker's families has been documented by Sukesi et al., (2017) based on their study in 2005. The studies show that the absence of mother in the families have shifted the functions of family care and child care to the husband or other family members. In addition to social change, economic and cultural changes also occured (Sukesi et al., 2017). These social changes potentially change people's views about the role and role of a father in the care and development of children.

\section{FATHER'S ROLE}

Many scholars (eg. Cortes, 2015; Zhou, Murphy, \& Tao, 2014) argue that the absence of mothers leads to low achievement, social disruption, emotional, and mental health of children. However, Wulan, et al., (2018) found that in the Indonesian context, the development of children left behind by migrant worker mothers will not be negatively affected as long as the fathers are able to provide the appropriate care needed by the children. Thus Wulan et al., (2018) recommends the involvement of fathers in childcare. In addition to that the extended family can also collaborate in child-care. Riasih (2018) also suggests the utilization of children's services institutions.

Many studies show that fathers have an important role in parenting. Traditionally the role of fathers in child development has a different realm than the involvement of mothers (Paquette, Coyl-Shepherd \& Newland, 2013; Dyer, Day, \& Harper, 2014; Wilson \& Prior, 2011). The fathers' parenting involvement influence the development and wellbeing of children, especially in the transition to adolescence (Cabrera, Tamis-LeMonda, Bradley, Hoffert, \& Lamb, 2000). What we mean by father's involvement is the active participation of a father related to child care which is delivered repeatedly and continuously from time to time and from a stage of development to the next stage of development. Father involvement is as important as mother involvement (Ahmeduzzaman \& Roopnarine, 1992). This dismissed the dominant discourse that it is the mother who plays an important role in a child's growth and development.

\section{CONCLUSIONS}

Changes in the structure of the family's role in the family of migrant workers in fact potentially challenge the hegemonic discourse of parenting. Existing studies on migrant worker's family are mostly about the impact experienced by children, the role of fathers in childcare, and interactions between fathers and children. Hence, it is very important for future researchers to examine more deeply the societal views about the changing structures of migrant workers' families. The focus that can be emphasized is how the community views the role of fathers and mothers in the care of young children, as well as how the father views his own caregiving role when the mother cannot be present in the caregiving.

\section{REFERENCES}

Ahmeduzzaman, M., \& Roopnarine J. T. (1992). Sociodemographic factors, functioning style, social support, and fathers' involvement with preschoolers in african-American families. Journal of Marriage and Family, 54(3), 699-707.

Arnold, S., \& Wall, G. (2007). How is involved fathering? An exploration of the contemporary culture of fatherhood. Gender and Society, 21(4), 508-527. doi: 10.1177/0891243207304973.

Asriani, D. D., \& Amalia, E. (2015). Jejak perempuan buruh migran dalam masyarakat ASEAN 2015. Jurnal Ilmu Sosial dan Ilmu Politik, 18(2), 147-159. ISSN 1410-4946. 
Bank Indonesia. (2019). Remitansi TKI, TKA serta selisihnya (TKI-TKA) Periode 2013-2018. Retrieved from

https://databoks.katadata.co.id/datapublish/2019/04/08/r emitansi-tenaga-kerja-indonesia-surplus-us-75-miliarpada-2018

Cabrera, N. J., Tamis-LeMonda, C. S., Bradley, R H., Hofferth, S., \& Lamb, M. E. (2000). Fatherhood in the twenty-first century. Child Development, 71(1), 127136. doi: 10.1111 / 1467-8624.00126.

Chae, J. Y., \& Lee, K.Y. (2011). Impacts of Korean fathers' attachment and parenting behaviour on the children's social competence. Social Behaviour and Personality, 39(5), 627-644. doi:

10.224/sbp.2011.39.5.627.

Cortes, P. (2015). The Feminization of international migration and its effects on the children left behind: Evidence from the Philippines. World Development, 65, 62-78. doi:10.1016/j.worlddev.2013.10.021

Dyer, W. J., Day, R.D., \& Harper, J.M. (2014). Father involvement: Identifying and predicting family members' shared and unique perceptions. Journal of Family Psychology, 28(4), 516-528. doi: http://dx.doi.org/10.1037/a0036903.

Hobson, L., \& Noyes, J. (2011). Fatherhood and children with complex healthcare needs: Qualitative study of fathering, caring and parenting. BMC Nursing, 10(5), 1-13. doi: 10.1186/1472-6955-10-5.

Hugo, G. (2002). Effects of international migration on the family of Indonesia. Asian and Pacific Migration Journal, 11(1), 13-46. https://doi.org/10.1177/011719680201100102.

Lam, T., \& Yeoh, B. S. A. (2016). Migrant mothers, left-behind fathers: the negotiation of gender subjectivities in Indonesia and the Philippine. Gender, Place \& Culture, ISSN: 0966-369X (Print) 1360-0524 (Online), doi: 10.1080/0966369X.2016.1249349.

Lam, T., \& Yeoh, B. S. A. (2019). Parental migration and disruptions in everyday life: reactions of left-behind children in Southeast Asia. Journal of Ethnic and Migration Studies, ISSN: 1369-183X (Print) 1469-9451 (Online). doi: 10.1080/1369183X.2018.1547022.

Mulyana, S., Kismiyati, E. K., \& Meria, O. (2019). Orang Tua Untuk Anak Kiri Di Balik Keluarga Pekerja Migran: Studi Di Jawa Barat. International Journal of Low, Government and Communication, 4(15), eISSN: 0121763.
Paquette, D., Coyl-Shepherd, D. D., \& Newland, L. A. (2013): Fathers and development: new areas for exploration. Early Child Development and Care, 183(6), 735-745.

http://dx.doi.org/10.1080/03004430.2012.723438.

Purwatiningsih, S. (2016). Respons anak-anak migran terhadap migrasi internasional di perdesaan Ponorogo. Populasi, 24(1), 57-71.

Pusat Penelitian Pengembangan dan Informasi BNP2TKI. (2019). Data penempatan dan perlindungan tenaga kerja Indonesia tahun 2019 (Periode 1 Juni 2019) [Data]. Retrieved from

http://www.bnp2tki.go.id/uploads/statistik/images/data 22-05-

2019_Laporan_Pengolahan_Data_BNP2TKI__Bulan _APRIL.pdf

Raharto, A. (2016). Pengambilan keputusan Tenaga Kerja Indonesia (TKI) perempuan untuk bekerja di luar negeri: Kasus Kabupaten Cilacap. Jurnal

Kependudukan Indonesia, 12(1), 39-54. p-ISSN : 19072902 (Print), e-ISSN : 2502-8537 (Online).

Rania, D. (2018, February). Tak Hanya Indonesia, ini 4+ Negara ASEAN yang Paling Banyak 'Sumbangan' Tenaga kerja Domestik. Hipwee.com. Retrieved from http://hipwee.com/feature/tak-hanya-indonesia-ini-4negara-asean-yang-paling-banyak-sumbangan-tenagakerja-domestik/

Riasih, T. (2018). Pola dan strategi pengasuhan anak oleh pekerja migran migran di Kota Bandung. Jurnal Ilmiah Pekerjaan Sosial, 17(1).

Sukesi, K., Endang, S., Agustina, S. H. W., \& Nur, B. (2017). Changes in socio-economic and cultural behavior of female indonesian migrant workers.

Habitat, 28(3), 114-121 doi:

10.21776/ub.habitat.2017.028.3.16.

Sumardiani, F. (2014). Peran serikat buruh migran indonesia dalam melindungi hak tenaga kerja Indonesia di luar negeri. Pandecta, 9(2).

Wilson, K. R., \& Prior, M. R. (2011). Father involvement and child well-being. Journal of Paediatrics and Child Health, 47, 405-407. doi:10.1111/j.1440-1754.2010.01770.xjpc_1770...lj.

Wulan, T. R., Shodiq, D., Wijayanti, S., Lestari, D. W. D., Hapsari, A. T. E., Wahyuningsih, \& Restuadhi, H. (2018). Ayah tangguh, keluarga utuh : Pola asuh ayah pada keluarga buruh migran perempuan di Kabupaten Banyumas. Jurnal Ilmu Keluarga \& Konseling, 11(2), 
84-95. ISSN : 1907 - 6037, e-ISSN : 2502 - 3594. doi: http://dx.doi.org/10.24156/jikk.2018.11.2.84.

Yulindrasari, H, \& McGregor, K. (2011).

Contemporary discourses of motherhood and fatherhood in ayah bunda, a middle class Indonesian parenting magazine. Marriage and Family Review, 47(8), 605-624.

Zhou, M., Murphy, R., \& Tao, R. (2014). Effects of parents' migration on the education of children left behind in rural China. Population and Development Review, 40(2), 273-292. https://doi.org/10.1111/j.17284457.2014.00673.x 